\title{
Development of Scientific Learning System Based on Character Education (Honest, Discipline, Self-Confidence) in MTs-Al Maidah Deli Serdang Regency
}

\author{
Julianto Hutasuhut \\ Universitas Muslim Nusantara AI-Wasliyah, Medan, Indonesia \\ juliantohts@umnaw.ac.id \\ ${ }^{*}$ Corresponding Author
}

How to Cite : Hutasuhut, J. (2019). Development of Scientific Learning System Based on Character Education (Honest, Discipline, Self-Confidence) in MTs-Al Maidah Deli Serdang Regency. International Journal for Educational and Vocational Studies, 1 (7), 791-794

\section{ARTICLE HISTORY}

Received: 3 September 2019

Revised: 12 October 2019

Accepted: 2 November 2019

KEYWORDS

Scientific Learning;

Islamic Character Education;

\begin{abstract}
A development must start from the human factor, namely education, organization and discipline. Therefore, aspects and problems of education are the most important elements that must be addressed immediately so that national development goals can be better achieved. One area that needs attention in the field of education development is the village of Kotasan located in Galang District, Deli Serdang Regency, North Sumatra. The majority of the population is educated middle to lower causing most of the population is still living from the agricultural sector. Seeing the existing phenomena and if this condition is allowed to continue then it is feared that the welfare of the community will lead to worse conditions. So with this dedication the team will try to find solutions to educational problems that are more beneficial for the Kotasan village community. This service aims to: 1). Designing teacher working groups in applying scientific learning, 2). Designing the learning process using a scientific learning model based on Islamic character education, 3). Designing learning material that will be applied by teachers in scientific learning based on Islamic character education. The method used in this service is coaching techniques. Expected outputs from this dedication are ISSN journals, mass media and activity videos. In the process of character evaluation in every aspect, in general get a value, namely (1) Honesty as much as $90 \%$, (2) Discipline as much as $80 \%$, and (3) confidence as much as $85 \%$. Then in the process of character evaluation in each aspect of points in particular there are 10 points get a value, namely: (1) honest in action $78 \%$, (2) honest in words $80 \%$, (3) admit mistakes $70 \%$, (4) wake up on time morning $83 \%$, (5) prayer 5 time $90 \%$, (6) diligently praying $84 \%$, (7) attending ceremonies and on time $63 \%$, (8) gathering assignments on time $72 \%$, (9) able to be a leader for example Imam prays $74 \%$, and (10) $80 \%$ practice test.
\end{abstract}

This is an open access article under the CC-BY-SA license.

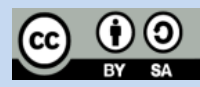

\section{INTRODUCTION}

Character education in this decade is an issue in school life. With this program the government and the community are expected to be able to work together to overcome a variety of increasingly widespread social problems. As explained by Schumacher (2002), development does not start with goods, but must start with people, namely their education, organization and discipline. So without these three elements the goal of a development will be difficult to achieve. Furthermore, with Islamic education, it is expected that every school in Indonesia is able to produce human resources who always strive to perfect faith, have good faith, have good morals and have good ethics. Kusno (2012) explained in more detail, that Islamic character is a trait attached to a person or object that shows identity, characteristics, obedience or Islamic message. The charact- er of Islam that is inherent in a person will be seen and influence one's way of thinking and acting, which is always imbued with Islamic values. When viewed in terms of behavior, people who have an Islamic character will always show their determination in their beliefs, their obedience in worship, and maintaining good relations between humans and the natural surroundings. In accordance with the 1945 Constitution of the Republic of Indonesia Article 31 paragraph (1) states that every citizen has the right to education, and paragraph (3) confirms that the Government strives and organizes a national education system that enhances faith and piety and noble character in in order to educate the nation's life which is regulated by law. To that end, all components of the nation are required to educate the life of the nation which is one of the goals of the Indonesian State. With this explanation it can be said 
that every citizen must be involved in the development of education including the children in the Tsanawiyah education bench in the village of Kotasan Galang. Galang is a sub-district and city in Deli Serdang district, North Sumatra. Galang Subdistrict has 29 villages and has 90 schools ranging from elementary schools (SD) to high schools (SMP and SMA). One of the villages in Galang sub-district is Kotasan village. The majority of the people's livelihoods are in the primary sector, namely farming and other parts are employees/employees and other services. From the survey activities conducted by the team, Amin Rahman as the General Section Kagalagur explained that the economic conditions of the Kotasan community are in the lower middle class.

This situation is the main reason, there are still many school-age residents who do not continue their education to college. Furthermore, this is the cause so that more people make agriculture as a source of livelihood and farmers as a hereditary profession. The quality of facilities and infrastructure in the village of Kotasan and even Galang District itself is still concerning. Though education is one of the important factors in determining the progress and welfare of a community group. Therefore the availability of educational facilities and infrastructure in the form of human resources and physical facilities is very important. Success in education is closely related to the availability of educational facilities. A description that can describe this condition is the Madrasah Tsanawiyah Al Maidah school. In this school there are still many lack of educational facilities and infrastructure. One of them is the lack of use of learning techniques used by teachers. For this reason, the service team wants to introduce scientific learning techniques based on Islamic character education.

\section{METHODS}

\subsection{Research Method on 5 stages of implementation}

There are five stages in the implementation of PKM in the scientific learning design program based on Islamic character education in MTS, namely:

\subsubsection{Preliminary Stage}

In this stage we prepare permits with related parties, prepare training practices, and prepare tools and materials.

\subsubsection{Socialization and Audience Stage}

Dissemination of the design of scientific learning based on Islamic character education. The implementation of this service involves only one group. Then the participants were given an explanation of scientific learning, then character education based on Islam. Then the participants are taught how to find problems that are appropriate for learning. The next activity is that the participants are directed to ask about the difficulties encountered during coaching practices or about things that are not yet understood by the teachers.

\subsubsection{Design Phase of Scientific Learning Based on Islamic Character Education.}

At this stage the service team will prepare the materials needed, then the team will model it directly followed by the Madrasah teacher Tsanawiyah AlMaidah step by step. The material provided is adjusted to the teacher's readiness level in receiving the material. This design demonstration is associated with problems that are often faced by teachers in the learning process. Then proceed to the stage of searching and processing problems and problem solving. The progress of its implementation will then be monitored so that it can find the problem at the same time it can find a solution to the problem. The material taught in this activity are: a). Learn the design of scientific learning based on character education that is Islamic. b). Learn the form of scientific learning design. c). Get to know scientific learning based on character education. d). Doing scientific learning design. e).Final evaluation phase.

At this stage of the evaluation activity, the team will adjust to the paradigm of the teachers who teach at Madrasah Tsanawiyah Al Maidah. The steps taken are as follows:

1. Contact the principals of the Tsanawiyah Madrasah School in Galang sub-district.

2. Explain the background and objectives of the program to be applied.

3. Motivating Tsanawiyah Madrasah teachers in Galang sub-district to be involved in this program. The trick is to invite the teachers to the Madrasah Tsanawiyah Al Maidah. In line with this there are several methods that have been developed to position Madrasah Tsanawiyah teachers in Galang sub-district. This needs to be done so that they not only become objects that passively accept the practice in this program, but are actively involved in carrying out this program in the hope that the objectives of this program are achieved well. The method used is participatory and dialogical, namely contacting the school principal and will provide the information to the teachers who are in the school. After that the teachers are gathered for socialization and deliberation so that the learning design program runs smoothly. If there are obstacles, the deliberation can be done together and find solutions to the problems encountered. After the meeting, the team as the PKM executive will assist and provide guidance to the target audience.

\subsection{Process Stages in The Field}

The implementation of this service is carried out in several stages, namely:

\subsubsection{Coordinate with related parties.}

The coordination carried out was with LP2M UMN Al Washliyah and with the school principal and Madrasah Tsanawiyah Al Maidah teachers in Kotasan village in writing. 


\subsubsection{Scheduling.}

The service team divides the schedule of activities per month, which is the first month to the eighth month.

\subsubsection{Dividing the types of activities to be carried out.}

Activities undertaken are socializing, administering administration, making teaching materials, coordinating, site visits, handing over certificates and reporting.

\subsubsection{Monitoring and evaluating the implementation of activities.}

Every activity carried out by the activity implementation team must monitor and evaluate the activities carried out. Evaluation can also be seen from learning activities in providing counseling or explanation resulting from the creation of a conducive atmosphere in providing explanations of the material. The teachers are very enthusiastic in participating in this activity because they find and acquire new knowledge that they can apply as a complement to teaching in the classroom by connecting scientific learning with Islamic character education that is needed by students in the current situation. Evaluation can also be seen from the counseling activities produced by creating a conducive atmosphere in providing the material. The headmaster and teacher Madrasa Tsanawiyah $\mathrm{Al}$ Maidah Kotasan express their gratitude to LP2M UMN Al Washliyah as the implementation team as well as the committee in this activity

\subsection{Data Collection Techniques}

The things that have been implemented are:

1. Conducting socialization activities to partners regarding community service regarding this PKM program.

2. Provide information about scientific learning based on Islamic character education.

3. Give examples of scientific learning by showing a media and learning model.

4. Creating a scientific learning process that is associated with character education in accordance with the conditions and circumstances that students need in the learning process

Then record the percentage progress of the data obtained from the number of outstanding students divided by the total number of students multiplied by $100 \%$. It is used to measure the value of aspect points measured in general and specific points or can be formulated as follows:

VALUE $=$ (number of measured or prominent students/ total number of students) x $100 \%$.

\section{RESULTS AND DISCUSSION}

In the process of character evaluation in every aspect, in general get a value, namely (1) Honesty as much as 90\%, (2) Discipline as much as $80 \%$, and (3) confidence as much as $85 \%$. Then in the process of character evaluation in each aspect of points in particular there are 10 points get a value, namely: (1) honest in action $78 \%$, (2) honest in words $80 \%$, (3) admit mistakes $70 \%$, (4) wake up on time morning $83 \%$, (5) prayer 5 time $90 \%$, (6) diligently praying 84\%, (7) attending ceremonies and on time $63 \%$, (8) gathering assignments on time $72 \%$, (9) able to be a leader for example Imam prays $74 \%$, and (10) $80 \%$ practice test. It can be seen that the average total value of $\%$ (character percentage) in general in terms of honesty, discipline, and confidence aspects is $85 \%$. This shows that the development of a scientific learning system based on Islamic character education can be classified as having a good impact in terms of these 3 character aspects.

Table 1. Character Aspect Table in General

\begin{tabular}{clcc}
\hline No & & Aspect & $\%$ Point \\
\hline 1 & Honest & $90 \%$ & \\
\hline 2 & Discipline & $80 \%$ & \\
\hline 3 & Self Confidence & $85 \%$ & \\
\hline & Average \% Character & $85 \%$ & \\
\hline
\end{tabular}

Table 2. Character Assessment in each aspect point

\begin{tabular}{|c|c|c|}
\hline No & Aspect & $\%$ Appropriateness \\
\hline 1 & Honest in Action & 78 \\
\hline 2 & Honest in words & 80 \\
\hline 3 & Admit mistake & 70 \\
\hline 4 & Wake up on time in the morning & 83 \\
\hline 5 & Always perform prayers 5 times & 90 \\
\hline 6 & Pray diligently & 84 \\
\hline 7 & The ceremony on time & 63 \\
\hline 8 & Timely task collection & 72 \\
\hline 9 & Able to be a leader & 74 \\
\hline \multirow[t]{2}{*}{10} & Practice test & 80 \\
\hline & Average $\%$ total & $77.4 \%$ \\
\hline
\end{tabular}




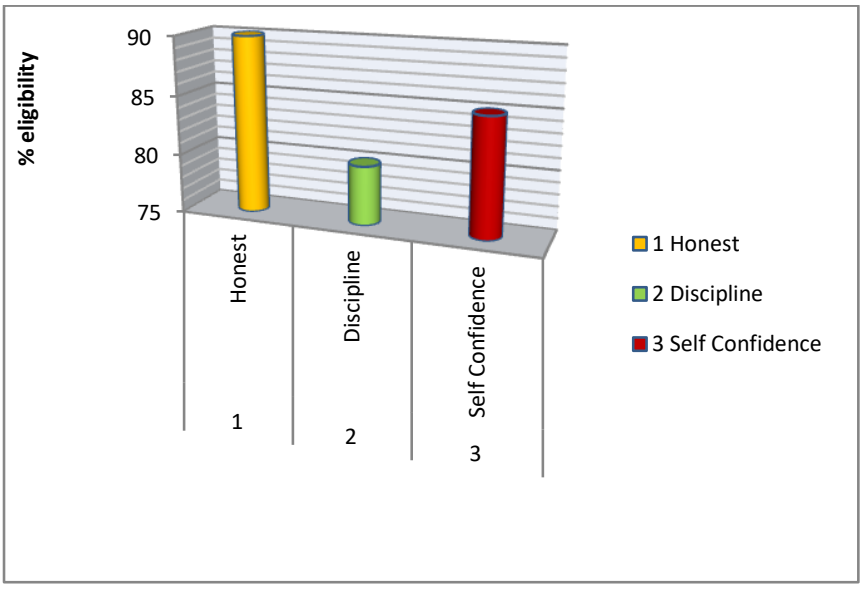

Figure 1. Draw bar graphic show Character Assessment table based on 3 main aspect

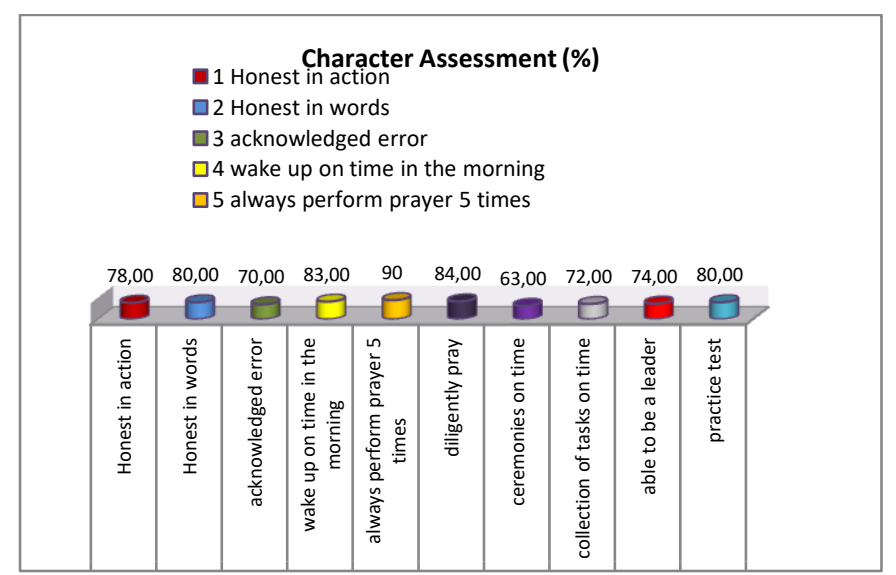

Figure 2. Draw bar graphic show Character Assessment table based on 3 main aspect

Meanwhile, if seen from the character assessment of each aspect point (as many as 10 specific assessment points) the highest score was obtained in the aspect of "working on the 5-time prayer" with a value of $90 \%$ which means that almost all students during the field observations worked on the 5-time prayer. And the lowest value was obtained from the aspect of the ceremony on time which received only $63 \%$. further research is needed regarding this matter. the total aspect average was $77.4 \%$ which was considered quite good.

\section{CONCLUSION}

This dedication activity has been carried out up to the stages of learning knowledge and also counseling about the development of Islamic character education based learning that is to the teachers of MTs Al Maidah Kotasan Galang. Next will be given the next stage plan in realizing in the form of training and strengthening in the making of scientific learning based on character education that gives rise to Islamic character (Honest, Discipline, and Self-Confidence). Create a scientific learning model that is closely related to the problem solving.

Religious character education (Islamic) needs to be developed as a step to build a noble generation. One step that can be applied is to integrate Islamic values in every scientific learning. For this reason, developing this teaching material is expected to be able to find a solution as expected from this dedication.

\section{REFERENCES}

Ahmad,D., Marimba. (2014). Pendidikan Anak. Tarsito, Bandung.

Ainiyah, Nur, (2013). Pembentukan Karakter Melalui Pendidikan Agama Islam, Jurnal:Al-Ulum Vol.13 No.1, Hal 25-38.

Irfanto, W. Y., Mustaji, M., \& Jacky, M. (2019). The Effect of Cooperative Learning Model Type Two Stay Two Stray and Learning Style on Social Sciences Learning Outcomes of Grade IV Elementary School Students. International Journal for Educational and Vocational Studies, 1(3), 212-216.

Ikawati, H. D., Majid, I. A., \& Anwar, Z. (2019). Effectiveness of the Superitem Learning Model on Students Learning Achievements. International Journal for Educational and Vocational Studies, 1(3), 184-188.

Kertajaya, (2012). Pendidikan Karakter. Erlangga, Jakarta.

Ki Hajar Dewantara. (2017). Pendidikan. blogspot pelangi, diakses tanggal 29 Oktober 2018.

Kusno, (2012). Pendidikan Karakter Religiusitas Berbasis Sains Matematika Melalui Pembelajaran Kolaboratif. Retrieved from digilib.ump:http://digilib.ump.ac.id/download.php?id $=3444$

Prambudi. (2013). Pendidikan Karakter Berbasis Islami. blogspot.com, diakses pada tanggal 30 Oktober 2018.

Pratama, Y. A., Sopandi, W., \& Hidayah, Y. (2019). RADEC Learning Model (Read-Answer-DiscussExplain And Create): The Importance of Building Critical Thinking Skills In Indonesian Context. International Journal for Educational and Vocational Studies, 1(2). 109-115.

Pohan, J. E. (2019). The Development of Inquiry Learning Model on Indonesian Language Lessons. International Journal for Educational and Vocational Studies, 1(4), 335-338.

Putra, P., \& Ikhsan, M. (2019). Mathematical Reasoning Ability and Learning Independence of High School Students Through Problem Based Learning Model. International Journal for Educational and Vocational Studies, 1(3), 217-223.

Sinamo, H. Jansen, (2002). Ethos 21, Institut Darma Mahardika, Jakarta. 